\title{
Investigating the use of mobile applications in everyday language learning
}

\author{
Nee Nee Chan* \\ Department of Communication \& Liberal Arts, \\ Sunway University, \\ Selangor, Malaysia \\ Email: nnchan@sunway.edu.my
}

*Corresponding Author

\section{Chin-Siang Ang}

Department of Psychology,

UCSI University,

Kuala Lumpur, Malaysia

Email: angcs@ucsiuniversity.edu.my

\begin{abstract}
The development of mobile phone applications has created a multiplicity of additional affordances and new ways of learning. In particular, mobile language learning applications such as online dictionaries and Google Translate combined with the technical affordances of smartphones and tablets are creating a new relationship between mobile learners and smart devices. In this exploratory study, a mixed method research design was used to understand how youth in Malaysia use their smart devices for learning languages and to uncover the extent of these learning experiences in their daily lives. 337 participants took part in a survey of their language learning experiences using mobile learning applications. Additionally, phenomenological interviews were conducted with 12 participants over a period of four months to uncover the lived experiences of their language learning. This paper presents the preliminary findings of the study which suggest learning is serendipitous, fragmentary and purposive; dependent on function and purpose. The findings may yield new understanding that may prove useful in its implications for formal and informal learning.
\end{abstract}

Keywords: MALL, learning languages, serendipitous, purposive, mobile learning, mobile apps, socio-cultural learning

Reference to this paper should be made as follows: Chan, N.N. and Ang, C-S. (2017) 'Investigating the use of mobile applications in everyday language learning', Int. J. Mobile Learning and Organisation 
Author

\section{Biographical notes:}

Nee Nee Chan is Principal Teaching Fellow and Head of Communication and Liberal Arts Department, Sunway University. Her research interests are in mobile learning, technology enhanced learning, communication and media technologies, student engagement and students' mental health.

Chin-Siang Ang is Assistant Professor and Head of Psychology Department, UCSI University. His research interests are in Psychology of Adolescence and Youth, Subjective Well-Being, Psychological Instrument Evaluation, Measurement, and Statistics.

\section{Introduction}

With increasing ownership to portable, smart devices such as smartphones worldwide, youth utilize these devices every day for entertainment, playing games, communication, and social networking. Current improvements in location aware and social software using Web 2.0 technologies (e.g., Instagram, Snapchat, What's App) or social networking sites (e.g., Twitter, Facebook) have made smartphones more ubiquitous and suggest more learning and teaching potential. The exponential growth of mobile applications (apps) has afforded many smartphone users with ubiquitous access to learning as seen in the various mobile apps used to learn languages and multiple skills.

In this evolving and technology-rich landscape, language learning practices are changing, impacted by learners' views of their available times for learning, the locations for their learning and their evolving perspectives of the significance of these fragments of learning experiences (Pachler et al., 2010; Crook, 2012; Liu et al., 2016). Hence, language learning in everyday environments has become more self-directed and learnercentered as the mobile devices assist and enhance the processes of resource sharing, creation and collaboration among communities of learners (Godwin-Jones, 2011; Lin et al., 2016; Wang, Liu and Hwang, 2017). Thus, there is a compelling need to understand how youth use their smart devices to learn in general and learning languages in particular, and if that learning takes place during everyday routines and in the interconnection of life, education, leisure and work. The aim of this paper is to investigate how youth in Malaysia use their smartphones to learn different languages, and the extent of their learning of languages in their everyday lives.

\section{Research study and research questions}

Mobile assisted language learning (MALL) is an increasing area of research with the development of mobile applications specially dedicated to language learning and the growing perception of the importance of acquiring multiple languages in an interconnected world (Kukulska-Hulme, Gaved, and Paletta, 2015; Viberg and Grönlund, 2012; Pettit and Kukulska-Hulme, 2011). This study explores how learners use their smartphones for language learning by examining the following research questions: 
1. How do learners use their smartphones for language learning in their everyday lives?

2. When and why do learners use their smartphones for language learning in their everyday lives?

\section{Literature review: mobile assisted language learning}

Mobile technologies are progressively influencing cultural practices and enabling new contexts for learning (Hwang and Tsai, 2011; Hwang, Chu and Lai, 2017; Pachler et al., 2012; Sung et al., 2015). The use of such technologies in education has however, been more gradual as educators contend with how understanding and application of these tools and devices in their classrooms could be more effectively used to support different types of learning (Crook, 2012; Jones et al., 2014; Sung et al., 2015). While mobile learning (m-learning) has been depicted as having the affordances of immediacy, permanency, interactivity, and accessibility (Ogata and Yano 2005), more recent definitions have moved from a predominantly technocentric focus to an increasing emphasis on the mobility of the learner and learner agency (Kukulska-Hulme and Shield, 2008; Sharples et al., 2007). m-learning is defined by Sharples et al. (2007, p. 225) as 'the processes of coming to know through conversations across multiple contexts.' Pachler et al. (2010, p. 6) adds to this conception of m-learning by proposing that learning occurs as 'a process of meaning making though acts of conversation on the basis of a pre-given, objectified cultural world.' This socio-cultural ecology of m-learning has the core constituents of agency, structures and cultural practices (Pachler et al., 2010). This paper adopts these definitions of m-learning with an emphasis on the use of smartphones for language learning in everyday environments.

Of increasing interest among researchers have been studies on Bring Your Own Device (BYOD) which refers to practices where smart devices are brought to learning or work environments with an emphasis on personalised learning and ownership (Kong and Song, 2015). In higher education contexts, BYOD studies have shown a blurring of time and space for learning leading to reported reflective inquiry and personal growth (Kong and Song, 2015). Hwang et al. (2017) review a large-scale Taiwanese mobile learning initiative, Prepare Your Own devices and Determination (PYOD) and found that PYOD has been well accepted and implemented by most high schools. In both BYOD and PYOD, the emphasis has been on learner autonomy, agency and contextualised learning.

Located within m-learning is an area of increasing interest to educators and researchers: mobile assisted language learning (MALL). Kukulska-Hulme and Shield (2008, pp. 273) define MALL in terms of 'its use of personal, portable devices that enable new ways of learning, emphasizing continuity or spontaneity of access and interaction across different contexts of use.' They argue that with different contexts and locations of use and the association of factors such as 'partial attention, shifting motivation, opportunistic scheduling of study, availability of physical space, real or perceived costs to the user, social conventions of device', learners will learn in new ways even with 'old content'(Demouy and Kukulska-Hulme, 2010, p. 218). In a review of mobile learning studies, Hwang and $\mathrm{Wu}$ (2014) found that contextual language learning could most likely be one of the most significant applications of digital and communication technologies.

It can be argued that MALL studies are anchored within existing Second Language Acquisition (SLA) theoretical frameworks. Some features of technology-mediated communication are beneficial for SLA when examined through the lens of sociocultural theory and SLA interactionist theory (Warschauer, 1997). Sociocultural theory contends that learning languages is a socially mediated process and people use mediated tools 
(language being the most important) to alter the world and to set their relationships (Ellis, 1997; Lantolf and Thorne, 2007). The interactionist theory of SLA argues that cognitive and sociocultural factors are important in language learning and suggests that incidental acquisition and L2 (second language) learning occurs through the process of interacting (Larsen-Freeman and Long 1991). The SLA interaction processes comprise 'input, apperception, semantic and syntactic comprehension, intake, integration into the learner's linguistic system and output' (Lin, 2014, p. 120). Mobile technologies enable human interaction to be readily conveyed, saved, archived, re-examined and edited, thereby encouraging reflection and interaction (Warschauer, 1997; Lin, 2014).

In a review of MALL developments, Kukulska-Hulme and Shield (2008) found that research studies comprised mainly content and design-based studies. There were mobile learning applications on vocabulary and grammar lessons (Thornton and Houser, 2005), the use of text messages to learn Italian outside the classroom (Levy and Kennedy, 2005; Kennedy et al., 2008), the development of 'short (from 30 seconds to 10 minutes) learning modules' to cater to the 'highly fragmented' attention of m-learners (Trifanova and Ronchetti, 2003, p. 1796) and more active language learning in museums (Wang et al., 2017). Viberg and Grönlund, (2012) reviewed MALL research (2007-2012) in the explicit area of second language acquisition and found that mobile technology could enhance learners' second language acquisition. However, it was noted that most of the reviewed studies were small in scale, experimental, and of short duration. This was a similar finding with Stockwell and Hubbard (2013)'s study of MALL, CALL and mobile learning literature. Thus, there would be reliability and scalability issues of the findings as there was also a shortage of cumulative research with most concepts and theories used only in one or a few studies.

While most of the research studies in MALL have been conducted in structured, teacher or researcher directed environments, there is increasing interest in language learning in informal environments where learners choose the time and place for their learning (Jones et al., 2014; Kukulska-Hulme, 2012). Progressively, there is interest in the personalized and cumulative learning that occurs in everyday practices. Merchant (2012, p. 772) describes 'everyday mobile practices' as the "doings, sayings and relating that constitute informal social practice' grounded on Schatzki (2002)'s social practice theory. There is emergent research on MALL practices in everyday environments (Song and Fox, 2008; Underwood, Luckin and Winters 2010, Wang et al., 2017), although a more detailed analysis of evidence-based technological experiences and MALL practices and their relationship to formal and incidental learning have been suggested (Jones et al., 2014; Merchant, 2012). With the scarcity in the literature of how smartphones are used to learn multiple languages in everyday settings, this study addresses this gap by exploring the everyday MALL practices and lived experiences of student participants in Malaysia to uncover the significance of this learning and its perceived value.

\section{Research methodology}

The research approach used in this study is Mixed Methods Research (MMR) which combines and integrates qualitative and quantitative research approaches. This study adopts pragmatism as its guiding philosophy founded on the principles developed by classical pragmatists such as James, Peirce, Dewey and later augmented in new directions by neo-pragmatists, Rorty, Putnam and Rescher (Johnson and Onwuegbuzie, 2004). Pragmatists search for the correct methodological mixes that can better answer their research questions, rather than any congruence to specific philosophical assumptions. The research design used here is that of the exploratory design - a two phase mixed methods 
design. There is firstly, a collection and analysis of quantitative data, after which the qualitative phase is designed such that it follows the results of the initial quantitative stage (Creswell and Garrett 2008; Gelo et al., 2008).

The qualitative research is based on the theoretical underpinnings of phenomenology which advocates the study of experience (or the appearance of things) and the nature and meaning of such experiences for one person or a group (Husserl, 1970; Giorgi, 1994). As 'human experience has a vertical depth, and methods of data gathering, such as shortanswer questionnaires with Likert scales that only gather surface information, are inadequate to capture the richness and fullness of an experience'(Polkinghorne, 2005, p. 138). The phenomenological interview was specifically chosen to uncover the technological experiences of the participants' language learning using smartphones. In this study, the qualitative phase functions to support and illuminate the findings of the primary, quantitative stage.

\subsection{Participants}

Given quantitative and qualitative data were both needed to answer the research questions in this study, the data were collected through surveys and interviews. The target population was youth ranging from 16-25 years old. Altogether, 400 close-ended structured surveys were distributed to participants in a tertiary institution. A total of 353 questionnaires were collected. The overall response rate was $90 \%$. Of the quantitative sample, we restricted our interview sample to participants whose score on the scale were no less than one standard deviation between the mean for semi-structured interview. This technique is called purpose sampling strategies for Typical Case Sampling to ensure that all participants had previous experience in using smartphone to learn languages. The semi-structured interviews used purposive sampling of 12 participants ranging from 1625 years old.

\subsection{Measures}

For the quantitative data, the research instrument used was a 3-page self-administered structured survey. The survey was specifically designed with the objectives of understanding the youths' use of smartphones to learn various languages, the contexts of their uses and their perceptions of the value and significance of this language learning. Given there is no available instrument to measure the research aim, a draft questionnaire was prepared based on a review of smartphone learning studies conducted in the past. The manner of use was assessed by the question: "On a scale from one to five, how often do you use your smartphone to learn languages?" Responses were collected in the following Likert item format: $1=$ Never; 2 = Seldom; 3 = Sometimes; 4 = Often; 5 = Very Often. Subsequently, respondents had to indicate one or more languages they learned using their smartphones from a list of pre-specified options. In addition, participants were asked to rate their preference of language learning applications (i.e., online dictionaries, Google Translate, and mobile apps from Google Android, AppStore or the Internet) on a 3-point scale where 1 denoting 'being the least used' and 3 denoting 'being the most used.' We further probed into participants' reasons in using smartphones to learn language. Participants were requested to rate their preference in order of importance, with 1 denoting 'being the least important' and 6 denoting 'being the most important.' At the function of using smartphone to learn language, participants had to choose three options out of six options (see the results for further details) and rated the importance of on a 3-point scale where 1 'being the least important' and 3 'being the most important'. Finally, two questions pertaining to the results/outcomes of using 
smartphone to learn language were asked. The questionnaire was pilot tested to detect any potential problems related to language or comprehension.

\subsection{Procedure}

As abovementioned, there were two approaches used in the collection of the data. Primarily, the survey was conducted in face to face sessions in a private university in Malaysia. Informed consent was obtained from participants individually and the questionnaires were distributed to participants from four different faculties in classrooms. The surveys were completed during class periods. Each participant was allowed 15 minutes to complete the surveys. The completed surveys were placed into a box by each participant to secure a sense of anonymity for themselves. Semi-structured phenomenological interviews were subsequently conducted and permission for the interviews and recordings was sought from the participants, and transcripts and interpretations were made available to them to comment (von Manen, 1990). This ensures accuracy of data analysis and interpretation to achieve better methodological rigour. To avoid researcher bias, the bracketing of presuppositions was carried out throughout the study and the researcher continually reflected to prevent preconceived biases from influencing her understanding of participants' descriptions (Husserl, 1970; Giorgi, 1994). Confidentiality of participants' data was adhered to and pseudonyms adopted in the analysis.

\subsection{Analytic Plan}

Data analysis was conducted using SPSS software. The data collected from the surveys were tabulated and results were presented using cumulative percentages of the participants' response to all questions in the survey. All results were described in terms of the usage of smartphones and their details, the use of smartphones for language learning purposes, and their perception of MALL in their everyday life. The analysis and interpretation of the interviews were based on von Manen (1990)'s analytic procedures. Emerging themes were coded into categories, re-evaluated and re-interpreted into shifting codes until the final themes emerged.

\section{Results and discussion}

\subsection{Sample Characteristics}

Table 1 shows the distribution of the sample profile. From the initial pool of 353 participants, 16 cases were deleted because of missing values for one or more of the variables in the analyses. Demographically, the majority of participants were in the age group from 21 to 25 years and females (See Table 1). About $94 \%$ of the participants were Malaysians although efforts were made to ensure that the participants were nationally diverse. The other international groups were close to that of the university statistics, with China students in the majority. In terms of their intensity of smartphone use, more than half of the participants noted they had used smartphones all the time, and only $1.8 \%$ of participants reported they seldom used them. The survey also included a question asking the types of mobile phone participants owned. The results showed that $53.7 \%$ of the participants owned Google Android OS while just 35\% owned the iPhone. The $0.3 \%$ that appear in Table 1 indicated that only one participant owned Palm. 
Table 1

Sample Profile of Participants $(N=337)$

\begin{tabular}{lcc}
\hline Characteristics & $\mathrm{n}$ & $\%$ \\
\hline Age group (years) & 115 & 34.1 \\
$16-20$ & 213 & 63.2 \\
$21-25$ & 9 & 2.7 \\
$26-30$ & & \\
& & \\
Gender & 121 & 35.9 \\
Male & 216 & 64.1 \\
Female & & \\
Nationality & 318 & \\
Malaysian & 1 & 94.4 \\
Iranian & 3 & .3 \\
Indonesian & 2 & .9 \\
Mauritian & 11 & .6 \\
China & 2 & 3.2 \\
Korean & & .6 \\
& & \\
Intensity of Smartphone use & 172 & 51.0 \\
All the time & 150 & 44.5 \\
Regularly & 9 & 2.7 \\
Occasionally & 6 & 1.8 \\
Seldom & 19 & \\
Primary mobile phone & 6 & 35.0 \\
iPhone & 118 & 0.3 \\
Google Android OS & 193 & 1.8 \\
Windows OS & & \\
Palm & & \\
Blackberry & & \\
\hline
\end{tabular}

\subsection{The Main Findings}

This section elaborates on the main findings of the analysis of the data. Comparisons of the importance attached to various reasons and functions of learning languages using smartphones are shown. Additionally, the perceptions of the interviewees to MALL are also discussed.

\subsubsection{New languages, new horizons}

Among the participants $(n=337)$, Table 2 illustrates the frequency of using smartphone to learn languages. $42.4 \%$ used smartphones sometimes to learn languages, followed by $31.8 \%$ who often do so, and $16.9 \%$ who seldom, and $8.9 \%$ who very often used their smartphones. 
Author

Table 2

Frequency of Using Smartphone to Learn Language $(N=337)$

\begin{tabular}{lcc}
\hline Frequency of Usage & $\mathrm{n}$ & $\%$ \\
\hline Very often (Hourly) & 30 & 8.9 \\
Often (Daily) & 107 & 31.8 \\
Sometimes (Weekly) & 143 & 42.4 \\
Seldom (Monthly) & 57 & 16.9 \\
\hline
\end{tabular}

Table 3 presents the types of languages the participants learned using smartphones. There were 17 languages reported by participants. On average, participants learned more than one language using smartphones. The greatest percentage of the participants used smartphone to learn English (84.9\%), followed by Mandarin (44.5\%) and Bahasa Malaysia (31.5\%). The least commonly reported languages were Portuguese, Cantonese, Hokkien, Hakka, and Sanskrit.

English Language is as the most popular choice as it is likely English is the medium of instruction in private colleges and universities in Malaysia and students have the motivation to improve their English proficiency to perform better in their studies. The status of English Language as a lingua franca and a global language means that increasingly learners perceive English as an important language to learn to improve their job opportunities and economic standing in life (Crystal, 2003; Dewey, 2007).

Table 3

Language Learning using Smartphones

\begin{tabular}{|c|c|c|}
\hline Language & $\mathrm{n}$ & $\%$ \\
\hline 1. English & 286 & 84.9 \\
\hline 2. Mandarin & 150 & 44.5 \\
\hline 3. Bahasa Malaysia & 106 & 31.5 \\
\hline 4. Korean & 52 & 15.4 \\
\hline 5. French & 43 & 12.8 \\
\hline 6. Japanese & 40 & 11.9 \\
\hline 7. Spanish & 24 & 7.1 \\
\hline 8. Thai & 19 & 5.6 \\
\hline 9. German & 6 & 1.8 \\
\hline 10. Arabic & 6 & 1.8 \\
\hline 11. Tamil & 6 & 1.8 \\
\hline 12. Dutch & 4 & 1.2 \\
\hline 13. Portuguese & 2 & 0.6 \\
\hline 14. Cantonese & 2 & 0.6 \\
\hline
\end{tabular}




$\begin{array}{lll}\text { 15. Hokkien } & 2 & 0.6 \\ \text { 16. Hakka } & 2 & 0.6 \\ \text { 17. Sanskrit } & 2 & 0.6\end{array}$

\subsubsection{Comparisons of the Methods of Learning Languages}

When asked which language learning application was mostly used, nearly half were more likely to learn digitally using Google Translate than online dictionaries and other mobile applications (see Table 4). This finding was expected as it is simply assumed that Google Translate is a free application and it allows translation of a word or phrase into one of more than 50 languages.

Table 4

Most Used Language Learning Applications $(N=337)$

\begin{tabular}{lcc}
\hline Learning Applications & $\mathrm{n}$ & $\%$ \\
\hline Online dictionaries & 93 & 27.6 \\
\hline Google Translate & 143 & 42.4 \\
\hline $\begin{array}{l}\text { Mobile apps like Duolingo, memrise, } \\
\text { YouTube, Learn English from Google } \\
\text { Android, App Store or the Internet }\end{array}$ & 101 & 30.0 \\
\hline
\end{tabular}

The 12 interview participants reported that they had downloaded online dictionaries into their smartphones for easy availability and use. Different apps are used in a combination to enable learners to maximize their learning, for example, Ismail reported:

I don't have a French dictionary, I just... Google Translate and I will always ... $\log$ in to YouTube and see how do they... how do they pronounce it.. Em..for that, em..I ask my friend like, 'is this correct' 'is this right or wrong'?

Ismail, L: 57-59

Online dictionaries and Google Translate may be the first application used to search for meaning of words and phrases. Participants understood that oral proficiency was also important and hence, other apps with oral exercises and pronunciation tips were used in tandem with interaction and practice with other learners. This suggests that learners were interacting with their mobile apps and other learners, and second language learning occurs through this input processing, syntactic and semantic comprehension, and subsequent integration into the learner's linguistic system and output (Ellis, 1997; Warschauer, 1997).

Additionally, the question included the reasons for using MALL apps for learning language purposes as shown in Table 5. For these purposes, the smallest percentage of the participants $(1.8 \%)$ indicated that they used MALL apps because they liked the vocabulary and the exercises, whilst the greatest percentage of them $(67.7 \%)$ indicated that they used MALL apps due to the convenience and accessibility of this type of 
Author

learning, which allows them to instantly learn languages in their daily life. About $15 \%$ of the participants were likely to use MALL apps as it is free (15.1\%). Additionally, participants liked the choice of being able to move from basic to advanced levels in their language learning $(5 \%)$. The scores of this question were highly skewed, indicating a clear preference between the reasons.

Table 5

Reasons for Using MALL Apps

\begin{tabular}{lcc}
\hline & Frequency & Percentage (\%) \\
\hline $\begin{array}{l}\text { I like that it convenient and I can } \\
\text { access it anytime }\end{array}$ & 228 & 67.7 \\
\hline I like that it is free & 51 & 15.1 \\
\hline $\begin{array}{l}\text { I like that the learning is presented in } \\
\text { an easy manner to learn }\end{array}$ & 28 & 8.3 \\
\hline $\begin{array}{l}\text { I like that I can move from basic level } \\
\text { to advanced levels using these apps }\end{array}$ & 17 & 5.0 \\
\hline $\begin{array}{l}\text { I like the pronunciation of the words } \\
\text { and the easy repetitions }\end{array}$ & 7 & 2.1 \\
\hline \begin{tabular}{l} 
I like the vocabulary and the exercises \\
\hline
\end{tabular}
\end{tabular}

Participants indicated their interest in learning new languages as it would increase their knowledge, broaden their horizons and enable them to get to know more friends as seen in Sam's quotation below:

Yes! (smiling) Like smartphones, like iPhones, the apps they have, not sure, I don't know what that category is called but I've come across apps where they have Learn English, Learn Malay, Learn French, Learn Thai. I downloaded Learn Thai as I've friends in Thailand. I want to learn a bit that's why I downloaded the app.

Sam, L: 97-100

In their pockets of time, in between classes or waiting for friends and when they are bored, they would use one of the applications (apps) to learn languages:

No, like when I'm bored, I like to disturb people..like 'Hi', 'How are you?', 'How're you doing?' Emm..first of all, Korean....Portuguese. Just for fun. And also knowledge.....like in my class, we ..I meet all kinds of people, ....so I make sure I'm prepared.

Ismail, L: 163, 168-173

Well, in my class, I'm the only Malay... So I like to learn all the cursing words... Chinese, some Korean, Hong Kong also. Actually the curse words..easier to learn... Google Translate.

Ismail, L: 149-156 
In many research studies portability, 'learning on the go', and convenience are the benefits cited in language learning using mobile devices (Kukulska-Hulme, 2012; Steel, 2012; Jones et al., 2014). Godwin-Jones (2011, p.11) suggests that smartphones are 'ideal for individualized informal learning' with learner agency foregrounded as learners user can 'determine which apps to acquire and how to use them.' In this study, the participants reported they were able to personalize their language learning to 'achieve learning tasks quickly and easily, spontaneously and habitually, so that time could be used profitably for language acquisition'(Steel, 2012, p. 877).

The survey question also took into consideration the preference functions of using smartphones to learn languages. Table 6 details the several functions that they used their mobile phones for learning languages. The greatest response was to know some basic phrases and words when they travel overseas (30\%). Analogously, 29.7\% learned languages to extend their knowledge and horizons. Interestingly, it is found that almost the same percentage of the participants had learned languages for conversation $(8 \%)$ or for an increase in their job prospects $(7.7 \%)$. Showing off to others was the least important function and that appealed to less than $5 \%$ of the participants.

Table 6

Functions for Learning Languages

\begin{tabular}{llc}
\hline & $\mathrm{n}$ & $\%$ \\
\hline $\begin{array}{l}\text { When I travel overseas and need to know } \\
\text { some basic phrases and words }\end{array}$ & 101 & 30.0 \\
\hline $\begin{array}{l}\text { To extend my knowledge and proficiency of } \\
\text { the language }\end{array}$ & 100 & 29.7 \\
\hline $\begin{array}{l}\text { To add on to my classroom learning and } \\
\text { practice in the particular language }\end{array}$ & 68 & 20.2 \\
\hline $\begin{array}{l}\text { To converse with my friends (in Malaysia and } \\
\text { abroad) in the language }\end{array}$ & 27 & 7.0 \\
\hline $\begin{array}{l}\text { To increase my job prospects by learning } \\
\text { other languages }\end{array}$ & 26 & 4.5 \\
\hline $\begin{array}{l}\text { To show off to others that I am able to speak } \\
\text { and write in other languages }\end{array}$ & 15 & \\
\hline
\end{tabular}

Johan, one of the participants explained his reasons for learning French, English and Chinese:

French must be for me. A lot of French terms in Culinary Arts. I feel happy I know a lot of terms and their meanings. Can improve in test this term...I think what goes on in my mind...it's a little bit hard. Learn Chinese because of friends. Learn French. Learn English because of some difficult words.

Johan, L: 66-70 


\section{Author}

French is a second language requirement for Johan's Diploma in Culinary Arts and he used his dictionary app to search for the meanings and pronunciations of French words and phrases. He learnt Chinese phrases and words to interact with his Chinese friends who use the language in their social interactions. Sam used to learn Japanese but since the course had ended, she used a Japanese language app to practise and communicate in Japanese. She believed that learning different languages would benefit her future and make her more 'marketable.'

I used to take lessons, Japanese lessons outside. I want to improve and no one can communicate with me at home, it's the app...Learn Japanese the easy way. Japanese 101. There is a lot of apps, actually. Ya, got to refresh my own memory.

Sam, L: 141-144

Thus, learning foreign languages is a trendy and fun way to learn anytime, anywhere utilizing the affordances of their smart devices, and yet in unison, for the more savvy among the youth, they see this activity as benefitting their future (See Table 3). These young people, hence, will go beyond the basic social etiquette phrases to continue learning the languages at a higher level with the help of the apps.

Regarding participants' results in language learning using smartphones (see Table 7), it is noted that participants could have indicated more than one result in language learning: $23 \%$ chose multiple reasons and $73 \%$ chose a single reason. More participants (see Table 7) indicated they have improved in languages proficiency (52.8\%), 26.7\% are able to converse in the target language, $22.3 \%$ able to use the language at both advanced levels. However, there were users who felt that their languages have not improved (12.2\%).

Table 7

Results in Language Learning by Using Smartphones

\begin{tabular}{lcc}
\hline & $\mathrm{n}$ & $\%$ \\
\hline $\begin{array}{l}\text { Yes, I am able to converse in } \\
\text { the language }\end{array}$ & 90 & 26.7 \\
\hline $\begin{array}{l}\text { Yes, I am able to use the } \\
\text { language at both advanced } \\
\text { levels }\end{array}$ & 75 & 22.3 \\
\hline $\begin{array}{l}\text { Yes, I can see that my results } \\
\text { in the languages at } \\
\text { school/college have improved }\end{array}$ & 178 & 52.8 \\
\hline No, I have not improved & 41 & 12.2
\end{tabular}

The survey also included a question asking about the remarks or praise for mastery of new languages. Table 8 below illustrates the responses of the participants. As opposed to the expected results, more than half of them indicated that they did not receive praise for mastery of new languages as the mastery level is more at awareness level $(54.9 \%)$. Therefore, it is probable that the participants' level of awareness of what they are mastering are probably very limited. Further, the results revealed a relatively similar ratio for other two remarks as Table 8 illustrates. 
Table 8

Remarks or Praise for Mastery of New Languages

\begin{tabular}{lcc}
\hline & Frequency & Percentage (\%) \\
\hline $\begin{array}{l}\text { Yes, my } \\
\text { teachers/friends/parents have } \\
\text { noticed my improvement in the } \\
\text { language }\end{array}$ & 90 & 26.7 \\
\hline $\begin{array}{l}\text { Yes, my } \\
\text { teachers/friends/parents have } \\
\text { praised/commented on my } \\
\text { improved results in } \\
\text { examinations }\end{array}$ & 75 & 22.3 \\
\hline $\begin{array}{l}\text { No, as my mastery of the } \\
\text { language is more at awareness } \\
\text { level }\end{array}$ & 185 & \\
\hline
\end{tabular}

\subsection{Discussion: The nature of language learning using smartphones}

Research findings on mobile learning, especially its empirical impact on learning outcomes are yet to be conclusive (Crook, 2012; Jones et al., 2014; Sung et al., 2015). As such, the conclusion of learning languages in this study can be only a tentative claim and of which needs to be further investigated.

The limitation of this study is that its sampling was largely derived from one tertiary institution and was not randomized. Hence, the findings cannot be generalizable to Malaysia or to other populations elsewhere. The scope of this study is focused but it does not investigate every issue in the MALL literature. As an exploratory, pilot study, these findings suggest insights into how learning languages using smart devices have been conducted either in everyday routines, the classroom or outside.

Clearly learning languages on the go in this study use the smartphones affordances of portability, immediacy, permanency, interactivity, and accessibility (Ogata \& Yano 2005; Kukulska-Hulme, 2012). As participants interact with their mobile apps and friends or teachers to practice the target languages, they reveal agency, structures and cultural practices in this socio-cultural ecology of learning (Pachler et al., 2010, Sharples et al., 2007). Learning languages using mobile apps in this study are at second or third language acquisition levels and mobile technologies enable interaction to be collected, archived, re-examined and edited, thus enabling reflection and interaction (Warschauer, 1997; Lin, 2014). Thus, in higher education contexts, teachers can utilise these affordances of the smartphones to design assignments that require target language in use and interaction with language users. Such language use could be recorded and re-examined by participants for critical inquiry and reflection, thus deepening the learning. Additionally, using location aware technologies, smartphones can be used to provide language learning progress such as behavioral patterns and individualized feedback (Liu et. al, 2016).

In this study, it is found that most of the language learning is incidental or serendipitous learning (Chan et al. 2015; Jones et al., 2014). Participants reported that their language learning were mostly at awareness level and were prompted by the 
motivation to learn basic phrases and sentences for their interactions with friends or teachers. As Malaysia is a multi-ethnic country, participants chose 17 languages which they were interested to learn more about. Beyond the usual languages of English, Malay, Chinese and Tamil (languages reflective of Malaysia's ethnic population), French, Japanese, Korean and Sanskrit were also chosen, suggesting the impact of international and global influences of foreign media. The predominant use of Google Translate suggest that participants may have immediate needs to learn some new language phrases on the go and the easy access and convenience of this app is appropriate to their needs. It would appear that respondents use surface approaches to learning (Marton and Säljö, 2005) when they are engaged in serendipitous learning episodes as their engagements with texts and images are usually superficial and exploratory.

Teachers in higher education could design and integrate these incidental learning episodes as part of a language learning project that requires participants to record such serendipitous learning with snapshots, recordings and their reflections of the usage of such terms. Mobile app designers such as those for the popular Google Translate could design a recall function that makes available such useful information as the frequency of use, contexts of usage and pictorial representations of the phrases that have been requested. This type of individualized feedback would enable learners to plan their language learning goals better (Liu et al., 2016) and could make serendipitous learning deepen into purposive and deep learning.

Some of the purposive learning practices described by participants have a planned element (Chan et al., 2015). They would deliberately put aside their leisure time to learn languages, either to improve their English Language proficiency or to practice pronunciation of a target language that they were currently learning. Several of the interview participants reported habitual learning of English, particularly at night before sleeping, where they had allocated time to learn using apps or reading e-books in English. Deep approaches to learning appears to be displayed in participants' purposive and intense engagement with language learning (Marton and Säljö, 2005). Teachers in higher education can utilise this functional importance of the English Language by engaging tertiary students to read e-books or show evidence of engagement with English Language learning apps as part of the individual student's learning journey.

The implication, thus, for universities and tertiary institutions could be to investigate further if these informal language learning practices could be utilized as an extension of classroom learning. Teachers could plan for the purposeful use of smartphones in their teaching using the relevant apps for language learning. Online dictionary and language learning applications could be further exploited to extend such learning practices outside the classroom or as 'seamless learning'(Looi et al., 2010) that is, as a bridge between formal and informal learning contexts. The design of learning assessments can be changed to have a greater focus of language in use in everyday settings and to emphasise the contextual nature of the learning. Participants, thus, may derive greater motivation and satisfaction from learning languages when they find that their incidental learning episodes are weaved into a larger picture of their learning goals and journey. Another implication for educators is to examine further the extent of the deep language learning that occurs in everyday practices. If there were purposive intent in some of these learning practices, there could be further studies to investigate the extent of the deep learning and whether such learning could be measurable.

More significantly, the nature of learning languages may have changed: learning is no longer constrained to classroom settings and teachers or mentors. With rapid changes in lifestyles and societal norms, learning languages is no longer positively viewed as prolonged, deep engagement of people with the target languages. It appears that the fragmentary and cumulative learning practices of today are the norm and new theories of learning would have to be conceptualized to explain the new ways of learning. It may be 
argued that Schatzki (2002)'s social practice theory could theorise 'everyday mobile practices" as the "doings, sayings and relatings" that constitute informal learning in everyday life (Merchant, 2012). Through the cumulative nature of these doings, sayings and relatings, learning takes place as there is repetition, review, reflection, analysis, application and evaluation. This could be the basis for future research.

\section{Conclusion}

This is an exploratory study using a mixed method design and a small, purposive sample. Findings, therefore are not generalizable. However, the findings suggest relevant and specific insights into mobile language learning that could be implemented in mobile language learning in higher education. Much of the language learning appears to be fragmented, incidental and driven by functionality. Such incidental learning patterns could be integrated into learning assessments in higher education that assess such usage of language in use. Reflective language learning journals could be used to promote critical inquiry and reflection. Hence, the design of homework and projects could be changed to integrate the use of such digital and communication technologies and can thus, show the shift in the pedagogical paradigm in teaching and learning (Liu et al., 2016).

Higher education teachers can use the smartphone affordances in their lessons, requiring students to record, take photographs, write notes and interact with each other using smart devices. Active learning can be promoted using 'playful', fun activities designed in language learning apps that take the students out of the classrooms into museums and other socio-cultural contexts for their learning (Wang et al., 2017). Additionally, the new knowledge that the participants mostly prefer using Google Translate and online dictionaries for language learning suggest that mobile apps designers should consider the simple functionality of these apps and intentionality of the users into their future designs. Individualised feedback such as learning behaviour, learning usage patterns and contexts of use would be paramount for users to assess their learning progress. This could form the basis of future research.

\section{References}

Chan, N.N., Walker, C. and Gleaves, A., 2015. An Exploration of Students' Lived Experiences of Using Smartphones in Diverse Learning Contexts using a Hermeneutic Phenomenological Approach. Computers \& Education, 82, pp.96106. Available at: http://dx.doi.org/10.1016/j.compedu.2014.11.001.

Creswell, J.W. and Garrett, A.L., 2008. The " movement" of mixed methods research and the role of educators. South African Journal of Education, 28, pp.321-333.

Crook, C., 2012. The "Digital Native" in Context: Tensions associated with Importing Web 2.0 Practices into the School Setting. Oxford Review of Education, 38(1), pp.63-80.

Crystal, D., 2003. English as a Global Language 2nd ed., Cambridge, UK: Cambridge University Press.

Demouy, V. and Kukulska-Hulme, A., 2010. On the Spot: Using Mobile Devices for Listening and Speaking Practice on a French Language Programme. The Journal of Open and Distance Learning, 25(3), pp.217-232. Available at: http://oro.open.ac.uk/24647/1/VD_and_AKH-Open_Learning_paper_2010.doc.

Dewey, M., 2007. English as a Lingua Franca and Globalization: An Interconnected Perspective. International Journal of Applied Linguistics, 17(3), pp.332-353.

Ellis, R., 1997. SLA Research and Language Teaching, Oxford, UK: Oxford University 
Author

Press.

Gelo, O., Braakmann, D. and Benetka, G., 2008. Quantitative and Qualitative Research: Beyond the Debate. Integrative Psychological \& Behavioral Science, 42(3), pp.266-90. Available at: http://www.ncbi.nlm.nih.gov/pubmed/18795385 [Accessed May 3, 2011].

Giorgi, A., 1994. A Phenomenological Perspective on Certain Qualitative Research Methods. Journal of Phenomenological Psychology, 25(2), pp.190-220.

Godwin-Jones, R., 2011. Emerging Technologies: Mobile Apps for Language Learning. Language Learning \& Technology, 15(2), pp.2-11.

Husserl, E., 1970. Logical Inverstigations, Vol I \& II (trans J.N. Findlay). New York: Humanities Press. (Original work published 1900).

Hwang, G. J., Chu, H. C., \& Lai, C. L., 2017. Prepare your own device and determination (PYOD): a successfully promoted mobile learning mode in Taiwan. International Journal of Mobile Learning and Organisation, 11(2), pp.87-107.

Hwang, G.-J. and Tsai, C.-C., 2011. Research Trends in Mobile and Ubiquitous Learning: A Review of Publications in Selected Journals from 2001 to 2010. British Journal of Educational Technology, 42(4), pp.E65-E70. Available at: http://doi.wiley.com/10.1111/j.1467-8535.2011.01183.x [Accessed November 25, 2012].

Hwang, G. J. and Wu, P. H., 2014. Applications, impacts and trends of mobile learning a review of 2008-2012 publications in selected journals. International Journal of Mobile Learning and Organisation, 8, pp. 83-95.

Jones, A. et al., 2014. Creating Coherent Incidental Learning Journeys on Smartphones Using Feedback and Progress Indicators: International Journal of Mobile and Blended Learning, 6(4), pp.75-92. Available at: http://services.igiglobal.com/resolvedoi/resolve.aspx?doi=10.4018/ijmbl.2014100105.

Kennedy, G.E. et al., 2008. First Year Students' Experiences with Technology: Are They really Digital Natives? Australasian Journal of Educational Technology, 24(1), pp.108-122.

Kong, S.C. and Song, Y., 2015. An experience of personalized learning hub initiative embedding BYOD for reflective engagement in higher education. Computers \& Education, 88, pp.227-240.

Kukulska-Hulme, A., Gaved, M. and Paletta, L., 2015. Mobile incidental learning to support the inclusion of recent immigrants. In 11th International Conference on Technology, Knowledge and Society: "Big Data and the Politics of Participation in the Digital Age”, 23-24 February 2015. Berkeley, CA: University of California, Berkeley.

Kukulska-Hulme, A., 2012. Language Learning Defined by Time and Place: A Framework for Next Generation Designs. In J. E.Diaz-Vera, ed. Left to my Own Devices: Learner Autonomy and Mobile Assited Language Learning, Innovation and Leadership In English Language Teaching. Bingley, UK: Emerald Group Publishing Limited, pp. 1-13. Available at: http://www.emeraldinsight.com/products/books/series.htm?id=2041-272x.

Kukulska-Hulme, A. and Shield, L., 2008. An Overview of Mobile Assisted Language Learning: From Content Delivery to Supported Collaboration and Interaction. ReCALL, 20(3), pp.271-289. Available at: http://oro.open.ac.uk/11617/.

Lantolf, J. and Thorne, S.L., 2007. Sociocultural Theory and Second Language Learning. In B. van P. \& J. Williams, ed. Theories in Second Language Acquisition. Mahwah, NJ: Lawrence Erlbaum.

Larsen-Freeman, D. \& Long, M.H., 1991. An Introduction to Second Language Acquisition Research, New York: Longman. 
Levy, M. and Kennedy, C., 2005. Learning Italian via Mobile SMS. In A. KukulskaHulme and J. Traxler, ed. Mobile Learning: A Handbook for Educators and Trainers. London: Taylor \& Francis, pp. 76-83.

Lin, H., 2014. Establishing an Empiricial Link between Computer-mediated Communication (CMC) and SLA: A Meta-Analysis of the Research. Language Learning \& Technology, 18(3), pp.120-147.

Liu, G-Z., Liu, T-C., Lin, C-C., Kuo, Y-L. and Hwang, G-J., 2016. Identifying learning features and models for context-aware ubiquitous learning with phenomenological research method. International. Journal of Mobile Learning and Organisation, 10 (4), pp.238-262.

Lin, Y.T., Kao, C.L. and Lan, Y.J., 2016. The effects of mobile learning on students' oral performance in Mandarin Chinese and their attitudes. International Journal of Mobile Learning and Organisation, 10 (1-2), pp.78-101. Available at: https://www.scopus.com/inward/record.uri?eid=2-s2.084969286752\&partnerID=40\&md5=431d73a948c30503f4a42adcb6edd950.

Looi, C.K. et al., 2010. Leveraging mobile technology for sustainable seamless learning: A research agenda. British Journal of Educational Technology, 41(2), pp.154-169.

von Manen, M., 1990. Researching Lived Experience: Human Science for an Action Sensitive Pedagogy, New York: State University of New York Press.

Marton, F. \& Säljö, R., 2005. Approaches to Learning. In F. Marton, D. Hounsell, \& N. Entwistle, eds. The Experience of Learning: Implications for Teaching and Studying in Higher Education. 3rd (Internet) edition. Edinburgh: University of Edinburgh, Centre for Teaching, Learning and Assessment., pp. 39-58.

Merchant, G., 2012. Mobile Practices in Everyday life: Popular Digital Technologies and Schooling Revisited. British Journal of Educational Technology, 43(5), pp.770782.

Ogata, H. \& Yano, Y., 2005. Knowledge Awareness for Computer-assisted Language Learning using Handhelds. International Journal of Learning Technology, 5(1), pp.435-449.

Pachler, N., Cook, J. \& Bachmair, B., 2010a. (a) Appropriation of Mobile Cultural Resources for Learning. International Journal of Mobile and Blended Learning, 2(1), pp.1-21. Available at: http://services.igiglobal.com/resolvedoi/resolve.aspx?doi=10.4018/jmbl.2010010101 [Accessed November 10, 2012].

Pachler, N., Cook, J. \& Bachmair, B., 2010b. Appropriation of mobile cultural resources for learning. International Journal of Mobile and Blended Learning, 2(1), pp.1-21. Available at: http://eprints.uwe.ac.uk/17507/.

Pachler, N., Seipold, J. and Bachmair, B., 2012. Mobile Learning: Some Theoretical and Practical Considerations. In K. Friedrich et al., eds. The "My Mobile” Handbook. Guidelines and Scenarios for Mobile Learning in Adult Education. pp. 11-16.

Pettit, J. and Kukulska-Hulme, A., 2011. Mobile 2.0: Crossing the Border into Formal Learning? In \& C. M. Lee, M.J., ed. Web 2.0-based E-learning: Applying Social informatics for Tertiary Teaching. Hershey, PA \& New York: IGI Global, pp. 192208. Available at: http://www.igiglobal.com/Bookstore/TitleDetails.aspx?TitleId=40272.

Polkinghorne, D.E., 2005. Language and meaning: Data collection in qualitative research. Journal of Counseling Psychology, 52(2), pp.137-145. Available at: http://psycnet.apa.org/journals/cou/52/2/137/.

R.B. Johnson and A.J. Onwuegbuzie, 2004. Mixed Methods Research: A Research Paradigm Whose Time Has Come. Educational Researcher, 33(7), pp.14-26. Available at: http://edr.sagepub.com/cgi/doi/10.3102/0013189X033007014. 
Author

Schatzki, T.R., 2002. The Site of the Social: a Philosophical Account of the Constitution of Social Life and Change., University Park, PA: Pennsylvania State University Press.

Sharples, M., Taylor, J. and Vavoula, G., 2007. A Theory of Learning for the Mobile Age. In K. Littleton \& P. Light., eds. The Sage Handbook of E-learning Research. London: Sage, pp. 221-247.

Song, Y. and Fox, R., 2008. Uses of the PDA for Undergraduate Students' Incidental Vocabulary Learning of English. ReCALL, 20(3), pp.290-314.

Steel, C., 2012. Fitting Learning into Life: Language Students' Perspectives on Benefits of using Mobile Apps. In M. Brown \& M. Hartnett, eds. Proceedings of ASCILITE 2012 25-28 November. pp. 875-880. Available at:

http://www.ascilite2012.org/images/custom/steel,_caroline_-_fitting_learning.pdf.

Stockwell, G. and Hubbard, P., 2013. Some Emerging Principles for Mobile-assisted

Language Learning. The International Research Foundation for English Language Education, (2013), pp.1-15. Available at: http://www.tirfonline.org/english-in-theworkforce/mobile-assisted-language-learning/some-emerging-principles-formobile-assisted-language-learning/.

Sung, Y.-T., Chang, K.-E. and Liu, T.-C., 2015. The Effects of Integrating Mobile Devices with Teaching and Learning on Students' Learning Performance: A MetaAnalysis and Research Synthesis. Computers \& Education, 94, pp.252-275. Available at: http://linkinghub.elsevier.com/retrieve/pii/S0360131515300804.

Thornton, P. and Houser, C., 2005. Using Mobile Phones in English Education in Japan. Journal of Computer Assisted Learning, 21(3), pp.217-228.

Trifanova, A. and Ronchetti, M., 2003. Where is Mobile Learning Going? In Proceedings of the E-learn Conference. pp. 1795-1801. Available at: http://www.science.unitn.it/ foxy/docs/Where is Mobile\%25 20Learning Goi ng (E-Learn2003).pdf.

Underwood, J., Luckin, R. and Winters, N., 2010. Managing Resource Ecologies for Mobile, Personal and Collaborative Self-directed Language Learning. In EUROCALL Conference September 2010. Bordeaux, France, pp. 8-11.

Viberg, O. and Grönlund, Å., 2012. Mobile Assisted Language Learning: A literature review. In Proceedings of the 11th International Conference on Mobile and Contextual Learning. pp. 1-8. Available at: http://du.divaportal.org/smash/record.jsf?pid=diva2:549644.

Wang, H. Y., Liu, G. Z. and Hwang, G. J., 2017. Integrating socio-cultural contexts and location-based systems for ubiquitous language learning in museums: A state of the art review of 2009-2014. British Journal of Educational Technology, 48(2) 653671.

Warschauer, M., 1997. Computer-mediated Collaborative Learning: Theory and Practice. The Modern Language Journal, 81(4), pp.470-481.

\section{List of Tables}

\begin{tabular}{|l|l|l|}
\hline Table 1 & Sample Profile of Participants $(N=337)$ & $\mathrm{P} 8-9$ \\
\hline Table 2 & Frequency of Using Smartphone to Learn Language $(N=337)$ & $\mathrm{P} 9$ \\
\hline Table 3 & Language Learning using Smartphones & $\mathrm{P} 10$ \\
\hline Table 4 & Most Used Language Learning Applications $(N=337)$ & $\mathrm{P} 10-11$ \\
\hline Table 5 & Reasons for Using MALL Apps & $\mathrm{P} 11$ \\
\hline Table 6 & Functions for Learning Languages & $\mathrm{P} 13$ \\
\hline Table 7 & Results in Language Learning by Using Smartphones & $\mathrm{P} 14$ \\
\hline
\end{tabular}


